EXTENDED REPORT

\title{
Joint erosion in rheumatoid arthritis: interactions between tumour necrosis factor $\alpha$, interleukin 1, and receptor activator of nuclear factor $\kappa B$ ligand (RANKL) regulate osteoclasts
}

\author{
D O' Gradaigh, D Ireland, S Bord, J E Compston
}

Ann Rheum Dis 2004;63:354-359. doi: 10.1136/ard.2003.008458

See end of article for authors' affiliations

Correspondence to:

Correspondence to:
Dr D O' Gradaigh, Bone

Research Group,

Department of Medicine,

University of Cambridge

School of Clinical

Medicine, Addenbrooke's

Hospital, Cambridge CB2

2QQ, UK; dogradaigh@

camrheum.fsnet.co.uk

Accepted 8 July 2003
Background: Osteoclasts, specialised bone resorbing cells regulated by RANKL and M-CSF, are implicated in rheumatoid joint erosion. Lymphocyte-monocyte interactions activate bone resorption, this being attributed to tumour necrosis factor $\alpha$ (TNF $\alpha)$ and interleukin $1 \beta$ (IL1 $\beta)$ enhanced osteoblast expression of RANKL. In animal studies, TNF potently increases osteoclast formation in the presence of RANKL. RANKL-independent osteoclastogenesis also occurs, though IL1 is required for resorptive function in most studies. These inflammatory cytokines have a pivotal role in rheumatoid arthritis,

Objective: To study the interactions of TNF $\alpha$ and IL1 $\beta$ with RANKL, particularly the time course of the interactions and the role of lymphocytes.

Method: Cultures of lymphocytes and monocytes (osteoclast precursors) or of purified CD1 $4^{+}$cells alone (osteoclast precursors) were exposed to various combinations of TNF $\alpha$, RANKL, and IL1 $\beta$ or the inhibitors osteoprotegerin, IL1 receptor antagonist, or neutralising antibodies to RANKL or to IL1. Osteoclastogenesis and resorptive activity were assessed on microscopy of dentine slices.

Results: TNF $\alpha$ potently increased osteoclast proliferation/differentiation in the presence of RANKL. This effect was greatest when RANKL was present before but not after exposure of osteoclast precursor cells to $\mathrm{TNF} \alpha$. The resorptive activity of osteoclasts generated by TNF $\alpha$ in the absence of RANKL was critically dependent upon IL1, which was expressed by lymphocyte-monocyte interaction.

Conclusion: TNF $\alpha$ potently enhances RANKL mediated osteoclast activity. Interactions between TNF $\alpha$ and IL1 also result in osteoclastic activity independently of RANKL. These findings will inform therapeutic approaches to the prevention of joint erosion in rheumatoid arthritis.
O steoclastic bone resorption has been implicated in the pathogenesis of joint erosion in rheumatoid arthritis (RA). ${ }^{12}$ Osteoclasts form from circulating monocytic precursors in the presence of the key signal RANKL (receptor activator of nuclear factor $\mathrm{\kappa B}$ ligand). ${ }^{3}$ These cells also require monocyte-colony stimulating factor $(\mathrm{M}-\mathrm{CSF}),{ }^{4}$ both factors normally being expressed by osteoblasts during physiological bone remodelling. Expression of RANKL has been demonstrated in rheumatoid synovial $\mathrm{T}$ cells and fibroblasts. ${ }^{5-7}$ However, as T cell expression of RANKL occurs on activation in most inflammatory settings, it is likely that the osteoclast formation in RA is a consequence of a highly osteoclastogenic environment which involves interactions between RANKL and other (inflammatory) signals, and between the monocytic precursors of the osteoclasts and other cell types.

Lymphocytes and macrophages interact in the generation of tumour necrosis factor $\alpha$ (TNF $\alpha)$ and interleukin (IL) 1 , cytokines pivotal in the pathogenesis of the joint inflammation and damage. ${ }^{89}$ Interactions between lymphocytes and monocytes have also been demonstrated in the production of an "osteoclast activating activity". ${ }^{10}$ As these studies used whole (fetal rat) bone cultures, it was unclear whether this osteoclast activating activity was mediated by marrow stromal cells, by osteoblasts on the bone surface, or directly affected bone resorbing osteoclasts. The soluble factors were subsequently identified as TNF $\alpha$ and $\operatorname{TNF} \beta^{11}$ and ILl $\beta{ }^{12}$ cytokines that act indirectly by up regulating osteoblast expression of RANKL. ${ }^{13}$

More recently, in vitro studies using soluble RANKL without stromal/osteoblast cells have explored the direct effects of these cytokines on osteoclast precursors. Some authors have reported RANKL-independent TNF $\alpha$ effects on osteoclast precursors, ${ }^{14-16}$ whereas others have suggested that simultaneous ${ }^{17}$ or prior $^{18}$ exposure to RANKL is necessary. Furthermore, while TRAP positive multinucleate osteoclastlike cells formed in all cases, the addition of ILl was essential for, ${ }^{15}$ or significantly increased, ${ }^{14}$ the resorptive function of these cells. Using human precursor cells, Lader and Flanagan demonstrated that both cytokines increased osteoclast resorptive activity from human bone marrow cells and that the effect was critically dependent on the synthesis of prostaglandin $\mathrm{E}_{2} \cdot{ }^{19}$ These authors found that ILl $\alpha$ increased osteoclast cell number (defined as vitronectin receptor positive cells).

Given the importance of these cytokines in RA, we wished to understand better the interactions between RANKL, TNF $\alpha$, and ILI $\beta$ and their time course in osteoclastogenesis and activation from human peripheral blood mononuclear cells (PBMCs). In view of the potential interaction between monocytes and lymphocytes in osteoclastogenic cytokine responses ${ }^{1020}$ a particular aim of our study was to compare outcomes in cultures of mixed PBMCs (comprising

Abbreviations: CTR, calcitonin receptor; IL1, interleukin 1; ILIRa, interleukin 1 receptor antagonist; M-CSF, monocyte-colony stimulating factor; OPG, osteoprotegerin; PBMC, peripheral blood mononuclear cell; RA, rheumatoid arthritis; RANKL, receptor activator of nuclear factor $\kappa \mathrm{B}$ ligand; $\mathrm{TNF} \alpha$, tumour necrosis factor $\alpha$ 
lymphocytes and monocytic osteoclast precursors) and purified $\mathrm{CDI}^{+}$cells (monocytes including the osteoclast precursor). ${ }^{21}$

\section{MATERIALS AND METHODS Materials}

"Culture medium" for osteoclastogenesis comprised Eagle's minimum essential medium with penicillin, streptomycin, and glutamine (both from GibcoBRL) and 10\% heat inactivated fetal calf serum (Autogen Bioclear). Human recombinant soluble RANKL, TNF $\alpha$, ILl $\beta$, ILl receptor antagonist (ILlRa), and osteoprotegerin (OPG) were from Insight Biotechnology. Human recombinant M-CSF, and neutralising antibodies to RANKL (TRANCE), ILl $\alpha$, and ILI $\beta$ were from R\&D Chemicals. Magnetic cell separation and flow cytometry reagents were from Miltenyi Biotech except RPE conjugated anti-CD3 antibody (Dako). A polyclonal antibody to calcitonin receptor was purchased from Santa-Cruz (sc8859).

\section{Cell separation}

PBMCs were isolated from the freshly obtained whole blood of normal healthy donors by density gradient centrifugation (Histopaque-1077). The unsorted PBMCs were resuspended in culture medium at $5 \times 10^{5}$ cells/100 $\mu \mathrm{l}$ for culture or resuspended in phosphate buffered saline buffer and incubated with magnetic bead conjugated antibodies according to the manufacturer's protocol. Briefly, cells were incubated with anti-CD3 conjugated beads (10 minutes at $4^{\circ} \mathrm{C}$ ), washed, resuspended, and passed through a separation column mounted in a magnetic field. The unbound fraction was collected and incubated with anti-CDI4 conjugated antibodies ( 10 minutes at $4^{\circ} \mathrm{C}$ ), washed, resuspended, and separated as before, collecting the $\mathrm{CD} 14^{+}$cells. These were washed twice in medium then resuspended at $2 \times 10^{5}$ cells/ $100 \mu \mathrm{l}$. On each occasion, aliquots were fixed in $4 \%$ paraformaldehyde and incubated with FITC conjugated anti-CDI4 or RPE conjugated anti-CD3 antibodies, or with dual conjugate-negative control immunoglobulin for FACS analysis.

\section{Osteoclast cultures and bone resorption assay}

Methods were adapted from published reports. ${ }^{21}$ Unsorted PBMCs or purified $\mathrm{CDI}^{+}$cells were added to dentine slices $\left(4 \mathrm{~mm}^{2}\right)$ in the wells of a microtitre plate. After overnight incubation $\left(37^{\circ} \mathrm{C}\right.$ in $\left.5 \% \mathrm{CO}_{2}\right)$ in the cytokine combinations described below, slices were moved to a $6 \times 4$ well plate for 14 days culture. Media were completely removed and replaced with fresh media and cytokines every 2-3 days. M-CSF $25 \mathrm{ng} / \mathrm{ml}$ was present in all cultures and is abbreviated as $+\mathrm{M}$ in each experimental condition described below. To determine the dose-response to TNF $\alpha$, PBMCs were cultured in $30 \mathrm{ng} / \mathrm{ml}$ of RANKL with TNF $\alpha 0.1,1.0$, or $10 \mathrm{ng} /$ $\mathrm{ml}($ all $+\mathrm{M})$, after which $\mathrm{TNF} \alpha$ was used at $1 \mathrm{ng} / \mathrm{ml}$ in all subsequent experiments. Synergism between RANKL and $\mathrm{TNF} \alpha$ was tested in cultures of PBMCs or $\mathrm{CD} 14^{+}$cells with RANKL 5, 15, or $30 \mathrm{ng} / \mathrm{ml}(+\mathrm{M})$ and TNF $\alpha \mathrm{lng} / \mathrm{ml}$. In other experiments, cells were cultured in M-CSF $25 \mathrm{ng} / \mathrm{ml}$, adding RANKL $30 \mathrm{ng} / \mathrm{ml}$ and/or TNF $\alpha 1 \mathrm{ng} / \mathrm{ml}$ at the beginning (day 0 ) or after complete removal of culture media on day 4, 7, or 10. RANKL-independent osteoclastogenesis from cultures of cells with TNF $\alpha$ was tested by omitting RANKL or by adding OPG (200 ng/ml, a previously determined saturating dose) or neutralising antibody to RANKL ( $5 \mu \mathrm{g} / \mathrm{ml}$ ) immediately after cell separation and thereafter at each exchange of media. ILl $\beta$ ( $10 \mathrm{ng} / \mathrm{ml})$ was added to cells cultured in RANKL $30 \mathrm{ng} /$ $\mathrm{ml}(+\mathrm{M})$ during either the first or second week of culture. In later experiments, ILI $\beta(10 \mathrm{ng} / \mathrm{ml})$, the inhibitor ILlRa (20 $\mathrm{ng} / \mathrm{ml})$, or neutralising antibody to ILl $\alpha(1 \mu \mathrm{g} / \mathrm{ml})$ or to
ILl $\beta(1 \mu \mathrm{g} / \mathrm{ml})$ was added to $\mathrm{CD}^{+} 4^{+}$cells in TNF $\alpha 1 \mathrm{ng} / \mathrm{ml}$ $(+\mathrm{M}$, without RANKL) and compared with control conditions (RANKL $30 \mathrm{ng} / \mathrm{ml}+\mathrm{M}$ ).

At the end of the culture period, dentine slices were stained for TRAP activity or fixed and stained by an indirect immunoperoxidase technique for calcitonin receptor (CTR). After examination of this staining by light microscopy, cells were removed and the dentine slices were stained with toluidine blue $(0.1 \%)$ and examined under reflected light microscopy using image analysis software (Lucia G) to calculate the area of resorption.

\section{Data analysis}

The mean area (and standard deviation) of resorption for four to six dentine slices in each experimental condition was calculated, experiments being repeated in triplicate. Data were compared using the unpaired $t$ test, first performing logit transformation to normalise data where necessary (see "Results").

\section{RESULTS}

Flow cytometry of separated cell populations

Unsorted PBMCs comprised mainly lymphocytes ( $\sim 60 \%$ ) and monocytes $(\sim 12 \%)$. After depletion of CD3 cells, a highly purified $(>99 \%)$ population of $\mathrm{CDI}^{+}$cells was obtained by positive selection.

\section{TNF $\alpha$ increases osteoclastic bone resorption in the presence of RANKL}

Fourteen-day cultures of CD1 $4^{+}$cells or of PBMCs in RANKL and $\mathrm{TNF} \alpha(+\mathrm{M})$ generated typical CTR and TRAP positive multinucleate cells on dentine slices. In cultures of PBMCs with RANKL $30 \mathrm{ng} / \mathrm{ml}$, a dose-resorption correlation with TNF was noted, increasing from a mean (SD) of $23(4.6) \%$ at $0.1 \mathrm{ng} / \mathrm{ml}$ to 53.1 (15.8)\% at $10 \mathrm{ng} / \mathrm{ml}$ (fig lA). Adding $\mathrm{TNF} \alpha$ $\mathrm{l} \mathrm{ng} / \mathrm{ml}$ significantly increased the area of resorption of the dentine slices at each dose of RANKL (fig 1B), up to threefold when added to RANKL ( $5 \mathrm{ng} / \mathrm{ml}$ ), from $3.84(3.2) \%$ to 11.23 (9.7)\%.

\section{TNF $\alpha$ generates functional osteoclasts in the absence} of added RANKL only in mixed PBMC cultures

PBMCs cultured in TNF $\alpha 1 \mathrm{ng} / \mathrm{ml}$ and $\mathrm{M}-\mathrm{CSF} 25 \mathrm{ng} / \mathrm{ml}$ generated small numbers of osteoclastic resorption pits, occupying only 1.02 (SD 1.26)\% of the total dentine surface (fig 2A). OPG $200 \mathrm{ng} / \mathrm{ml}$ or neutralising antibody to RANKL was added to parallel PBMC cultures on cell isolation through the 14-day culture period. These PBMCs similarly formed functional osteoclasts in M-CSF with TNF $\alpha$ (fig 2B). In contrast, repeated experiments with $\mathrm{CDI}^{+}$cells cultured in the M-CSF and TNF $\alpha$ did not generate osteoclastic pits, though CTR positive cells were noted (fig 3).

\section{Timing of exposure to RANKL and TNF $\alpha$ is critical} When PBMCs were cultured in M-CSF $25 \mathrm{ng} / \mathrm{ml}$, RANKL $30 \mathrm{ng} / \mathrm{ml}$, and $\mathrm{TNF} \alpha \mathrm{lng} / \mathrm{ml}$ from the first day of culture, significant increase in resorption area was seen, as noted above. In contrast, adding TNF $\alpha$ on day 4,7 , or 10 of culture did not increase resorption area over controls (fig 4). When RANKL $30 \mathrm{ng} / \mathrm{ml}$ was delayed until the fourth day of culture, resorption was considerably less than in cultures where RANKL was present from the first day of culture (figs 4 and $5)$. Resorption was reduced in those cultures exposed to both TNF $\alpha$ and M-CSF rather than M-CSF alone before adding RANKL (1.4 (SD 1.23)\% or 2.9 (SD 1.54)\%, respectively, $\mathrm{p}=0.01)$, compared with $49.3 \%$ when RANKL and TNF $\alpha$ were present from the first day; fig 5). 

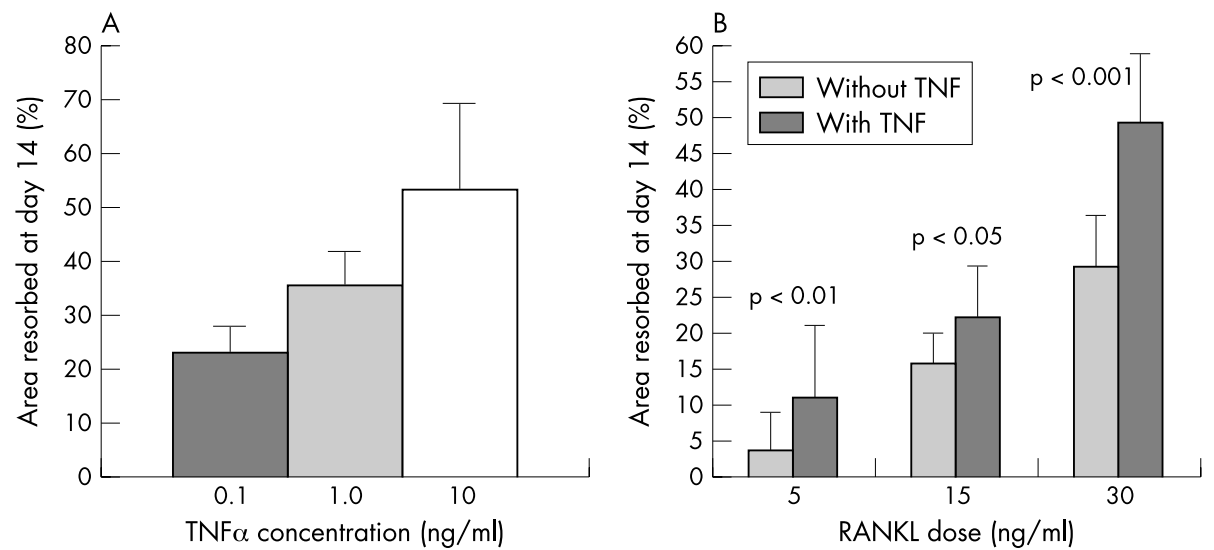

Figure 1 TNF $\alpha$ is synergistic with RANKL in osteoclast regulation. (A) Dose-resorption effect on area of osteoclastic resorption of dentine slices on adding TNF $\alpha$ in a range of doses to PBMCs cultured in RANKL $30 \mathrm{ng} / \mathrm{ml}$ and M-CSF $25 \mathrm{ng} / \mathrm{ml}$. (B) Effect on area of osteoclastic resorption of dentine slices of adding TNF $\alpha 1 \mathrm{ng} / \mathrm{ml}$ to RANKL at 5,15 , or $30 \mathrm{ng} / \mathrm{ml}$. Mean of four to six slices in three experiments; error bars are the standard deviation.

\section{RANKL-independent osteoclast function requires IL 1} The addition of exogenous ILl was not required in our experiments for the generation of functional osteoclasts from PBMCs cultured in M-CSF and TNF $\alpha$ alone. In view of experiments described earlier, ${ }^{15}$ we considered that ILl might be produced in these cultures. Osteoclastic bone resorption did not occur in PBMC cultured in M-CSF and TNF $\alpha$ in the presence of the ILl receptor antagonist (ILIRa). Furthermore, resorption of the dentine surface did occur in cultures of $\mathrm{CDI}^{+}$cells when ILl $\beta$ was added during the second week to M+TNF $\alpha$ (fig 3).

\section{DISCUSSION}

TNF $\alpha$ and ILl are critical cytokines in the pathogenesis of joint inflammation in RA. However, recent studies of biological treatments have suggested that these cytokines also influence joint erosion. ${ }^{22-24}$ In contrast, studies in animal models of arthritis suggest that bone erosion is exclusively mediated by RANKL. ${ }^{25}$ Therefore, gaining a greater understanding of the interactions between these cytokines is important.

The availability of soluble RANKL has enabled studies of in vitro osteoclastogenesis without the confounding effects of stromal or osteoblastic cells. Using human circulating osteoclast precursor cells, we confirmed that TNF $\alpha$ has a potent synergistic effect on RANKL induced osteoclastogenesis across a range of doses of both cytokines, as reported in animal studies. ${ }^{14-16}$ We also found that phenotypic (TRAP and CTR positive) and functional (resorptive) osteoclasts were consistently generated from PBMCs cultured in M-CSF and TNF $\alpha$ without adding RANKL or in the presence of saturating doses of the RANKL inhibitors OPG or a neutralising antibody. Positive staining with calcitonin receptor antibody and similar depth of resorption to pits formed by RANKL generated osteoclasts confirm that the resorption generated independently of RANKL was osteoclast mediated, in contrast with claims by some authors of nonosteoclast mediated resorption.

In murine ${ }^{14}{ }^{15}$ and rat $^{16}$ studies, TNF $\alpha$ directly induced the formation of TRAP positive multinucleate cells with resorptive function without addition of RANKL. The effect was completely abrogated by blocking the p 55 receptor, ${ }^{14}$ but was not affected by OPG-Fc. ${ }^{14}$ In contrast, Komine et al reported synergism between TNF and soluble RANKL but no RANKLindependent activity, ${ }^{17}$ and Lam et al concluded that macrophages had to be exposed to permissive levels of RANKL for $\mathrm{TNF} \alpha$ to promote osteoclast formation. ${ }^{18}$ In previous experiments we confirmed that $200 \mathrm{ng} / \mathrm{ml}$ of OPG completely inhibited osteoclast resorption generated by up to $30 \mathrm{ng} / \mathrm{ml}$ (soluble) RANKL, and we are not aware of any data to suggest that OPG is less potent in inhibition of membrane bound RANKL that might have derived from lymphocytes in the unsorted PBMC population. We added OPG or RANKL neutralising antibody from the earliest time at which significant cell-cell interactions between RANKL and its receptor were likely to occur (that is, immediately after
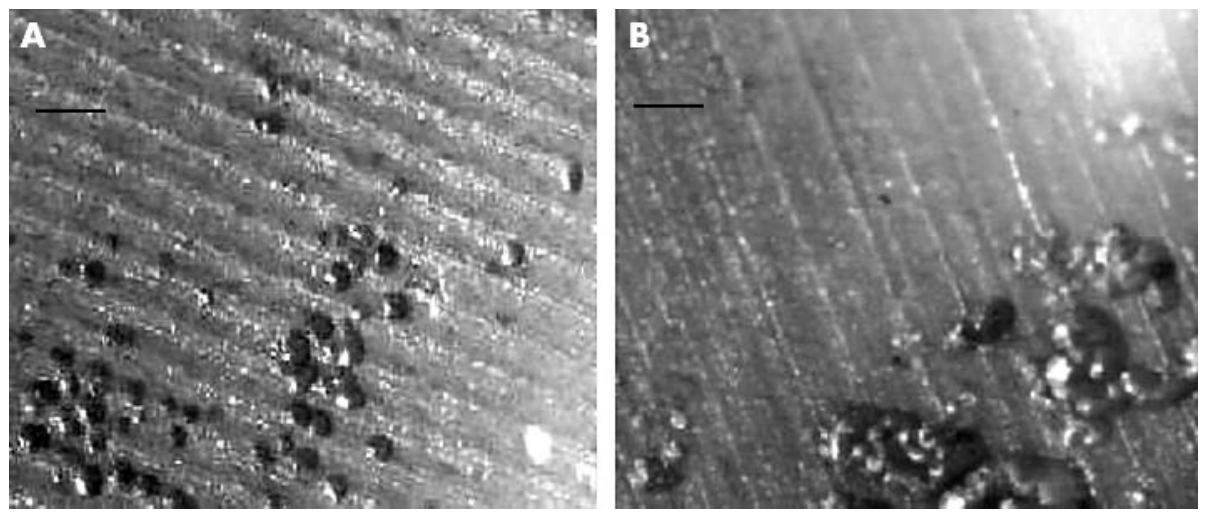

Figure 2 RANKL-independent osteoclast formation in cultures of PBMCs. Reflected light microscopy of dentine slices stained with toluidine blue showing individual and grouped resorption pits. (A) cells cultured in M-CSF and TNF $\alpha$ (1 ng/ml); (B) cells cultured in M-CSF, TNF $\alpha$ (1 ng/ml), and OPG $(200 \mathrm{ng} / \mathrm{ml})$. Bar $=50 \mu \mathrm{m}$. 

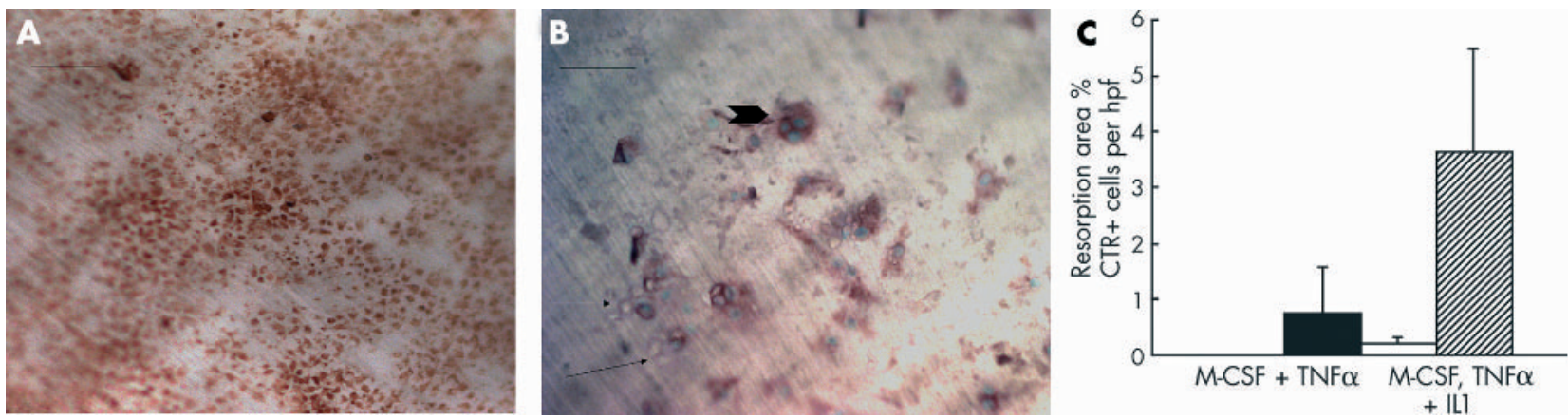

Figure 3 Osteoclastogenesis from CDI4 selected cells cultured in (A) M-CSF and TNF $\alpha$ or (B) in M-CSF, TNF $\alpha$, and IL1. Addition of ILI resulted in resorptive activity (pits shown by arrows) by CTR+ cells (arrow head), whereas in the absence of ILI, the CTR+ cells did not resorb. Bar (photomicrographs) $=50 \mu \mathrm{m}$. Staining by indirect immunoperoxidase method. Data from repeated experiments are shown in the graph (C). The number of CTR+ cells per high power field in the absence (black bar) or presence (hatched bar) of IL1 did not differ significantly. The resorption area was only measurable when ILI was added (white bar). Error bars are the standard deviation.

centrifugation/short incubations at $4^{\circ} \mathrm{C}$ with magnetic beads), ensuring that the data from these experiments can be reasonably interpreted as indicating RANKL-independent effects.

Further considering the requirement for RANKL in our studies, we were struck by the inability to generate osteoclasts from cultures of $\mathrm{CDI}^{+}$cells in M-CSF and $\mathrm{TNF} \alpha$, in contrast with PBMC cultures. This was confirmed in three separate experiments, in all of which a positive synergistic effect was noted in simultaneous cultures of $\mathrm{CDI}^{+}$cells in TNF with RANKL. We first considered that RANKL-independent osteoclastogenesis required a rare precursor that was not present at the lower cell density used. However, RANKL-independent osteoclastogenesis did not occur on increasing the $\mathrm{CDI} 4^{+}$cell density from $1 \times 10^{5}$ to $5 \times 10^{5}$ cells/well (data not shown). We next considered whether the lymphocytes (the predominant $\mathrm{CD}_{1} 4^{-}$cell type in PBMCs) were expressing RANKL, as reported in activated $\mathrm{T}$ cells. ${ }^{26}$ However, neither the addition of OPG nor of a neutralising antibody to RANKL inhibited or reduced the osteoclast formation in these cultures (fig 2B). In contrast with a previous report, ${ }^{15}$ the addition of ILl was not required in our study for fully functional osteoclast formation from PBMCs cultured in M-CSF and TNF $\alpha$. As ILl was subsequently found to be an important constituent of "osteoclast activating factor", which required interaction between lymphocytes and monocytes for its production, ${ }^{10}$ we investigated if interaction between lymphocytes and $\mathrm{CD} 14^{+}$monocytes was occurring in our PBMC cultures with the

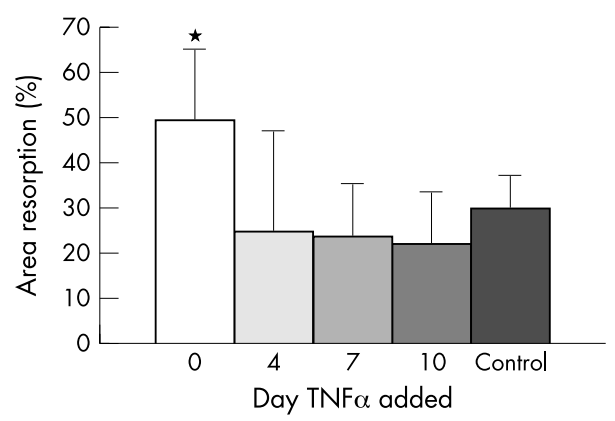

Figure 4 Effect of TNF $\alpha$ depends on timing of addition to cultures. PBMCs were cultured in M-CSF and RANKL, with TNF added at various time points. Significantly more resorption occurred when TNF $\alpha$ was added on day 0 (white bar) compared with control to which no TNF $\alpha$ was added (black bar), $p<0.001$. The resorption area was not increased when TNF $\alpha$ was added on day 4, 7 or 10. Mean of six slices in three experiments; error bars are the standard deviation. production of endogenous ILl. As addition of ILlRa or inhibition of ILl with neutralising antibodies to both forms of this cytokine (ILl $\alpha$ and $\beta$ ) prevented the RANKLindependent formation of osteoclasts in cultures of PBMCs, and ILl resulted in resorptive activity in cultures of $\mathrm{CD}_{1}{ }^{+}$ cells in M-CSF and TNF $\alpha$, we conclude that ILl is produced when T cells and monocytes interact (at least in the presence of TNF $\alpha$ ) and substitutes for RANKL. Other osteoclastogenic cytokines produced by lymphocyte-monocyte interaction include IL15 ${ }^{27}$ and IL17. ${ }^{28}$ The latter is believed to act exclusively through up regulation of osteoblast expression of RANKL, whereas IL15 acts directly on osteoclast precursors. ${ }^{27}$ Its role was not formally evaluated in the present study, although our data relating to ILl suggest that IL15 cannot substitute for RANKL in this way.

Using human osteoclast precursors, Kudo et al recently demonstrated similar TNF $\alpha$ mediated RANKL-independent osteoclast differentiation. ${ }^{29}$ In their experiments, purified $\mathrm{CDI}^{+}$cells also apparently generated resorption pits in response to TNF $\alpha$ and M-CSF without adding ILl. However, no details are provided and inhibitor studies with neutralising anti-ILl $\alpha$ antibodies were only carried out using unsorted PBMCs as precursors. Cells were cultured for 6 days before addition of TNF $\alpha$, with or without ILl or the neutralising antibody. Most significantly, OPG was also delayed until this time, and RANKL priming cannot be excluded in these

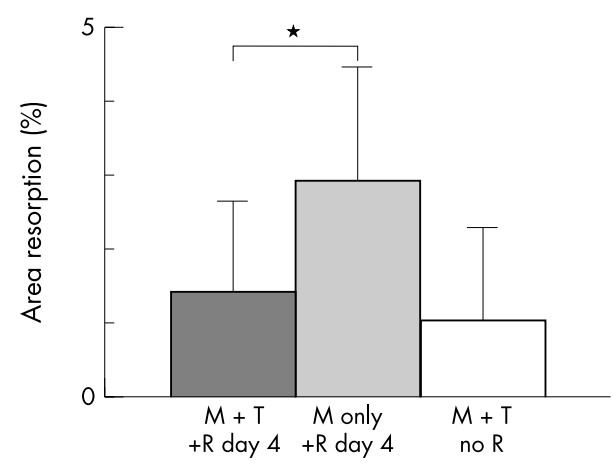

Figure 5 Exposure to TNF $\alpha$ before RANKL reduces osteoclastic resorption activity. PBMCs were cultured in M-CSF (light grey bar) or in $M-C S F$ with TNF $\alpha$ (dark grey bar) before adding RANKL after 4 days, and compared with cells treated with M-CSF and TNF $\alpha$ alone (white bar). Osteoclast resorption was reduced when cells were exposed to TNF $\alpha$ before RANKL ( $\left.{ }^{*} p=0.08\right)$. Mean of six slices in three experiments; error bars are the standard deviation. M, M-CSF $25 \mathrm{ng} / \mathrm{ml} ; \mathrm{T}$, TNF $\alpha$ $1 \mathrm{ng} / \mathrm{ml}$; R, RANKL $30 \mathrm{ng} / \mathrm{ml}$. 
experiments. These authors also investigated RANKLindependent osteoclastogenesis from cells extracted from the pseudomembrane of loosened hip arthroplasties. ${ }^{30}$ As RANKL expression has also been reported in this tissue, precursor priming again cannot be confidently excluded. Interestingly, Hirayama and colleagues recently reported that TNF $\alpha$ did not increase RANKL mediated osteoclastogenesis. ${ }^{31}$ However, these cultures were carried out with dexamethasone, which others from this group ${ }^{29}$ had already shown to inhibit the effects of TNF $\alpha$.

In murine osteoclastogenesis experiments, ${ }^{18}$ maximal response to TNF occurred when this cytokine was added 24 days after initial exposure to RANKL. In our study TNF $\alpha$ similarly affected the early phase of osteoclastogenesis-that is, during proliferation and differentiation of precursors. Erwig et al have also demonstrated the effect of initial cytokine exposure on subsequent differentiation of pluripotent macrophages. ${ }^{32}$ Our results from the experiments in which exposure to RANKL was delayed (fig 5) suggest that $\mathrm{TNF} \alpha$ drives pluripotent cells to differentiate away from the osteoclast lineage (or to apoptosis) unless they are simultaneously exposed to RANKL. The results support previous work $^{18}$ showing that prior exposure to RANKL is critical for $\mathrm{TNF} \alpha$ to increase osteoclastogenesis above that induced by RANKL alone, though RANKL-independent osteoclastogenesis also occurs. Other reports suggest that transforming growth factor $\beta$ may similarly support TNF $\alpha$ mediated osteoclastogenesis. ${ }^{20}{ }^{33}$

Our findings are consistent with recent advances in understanding downstream signalling pathways of $\mathrm{TNF} \alpha$, RANKL, and ILl (reviewed by Gravallese et al ${ }^{34}$ ). TNF $\alpha$ induces apoptosis, but in the presence of a survival factor (such as M-CSF or RANKL) augments signalling through shared pathways. ${ }^{35}$ ILl shares downstream signals with RANKL (for example, TRAF6) that are important in osteoclast activation (as opposed to osteoclastogenesis). This is consistent with the observation that this cytokine was necessary (in the absence of RANKL) for osteoclast resorptive function, though not for proliferation and differentiation of precursors.

In conclusion, we have shown that the synergism between RANKL and TNF $\alpha$ previously demonstrated in animal studies also occurs in cultures of human circulating osteoclast precursors, from which synovial osteoclasts derive. We have also shown that the timing of exposure to these cytokines is critical, and that ILl may substitute for RANKL in activation of $\mathrm{TNF} \alpha$ generated osteoclasts. In particular, our studies highlight the importance of interactions between lymphocytes and potential osteoclast precursors. These findings are particularly relevant in the pathogenesis of joint erosion in RA.

\section{ACKNOWLEDGEMENTS}

This work is supported by the Arthritis Research Campaign (Clinical Research Fellowship O0157) and by the Sackler Foundation (University of Cambridge). We are grateful to the University of Cambridge Centre for Applied Medical Statistics for advice.

\section{Authors' affiliations}

D O' Gradaigh, D Ireland, S Bord, J E Compston, Bone Research

Group, Department of Medicine, University of Cambridge School of

Clinical Medicine, Addenbrooke's Hospital, Cambridge CB2 2QQ, UK

\section{REFERENCES}

1 Gravallese EM, Harada Y, Wang JT, Gorn AH, Thornhill TS, Goldring SR. Identification of cell types responsible for bone resorption in rheumatoid arthritis and juvenile rheumatoid arthritis. Am J Pathol 1998;152:943-51

2 Romas E, Bakharevski O, Hards DK, Kartsogiannis V, Quinn JMW, Ryan PFJ, et al. Expression of osteoclast differentiation factor at sites of bone erosion in collagen-induced arthritis. Arthritis Rheum 2000;43:821-6.
3 Yasuda H, Shima N, Nakagawa N, Yamaguchi K, Kinosaki M, Mochizuki S-I, et al. Osteoclast differentiation factor is a ligand for osteoprotegerin/ osteoclastogenesis inhibitory factor and is identical to TRANCE/RANKL. Proc Natl Acad Sci USA 1998:95:3597-602.

4 Fujikawa Y, Sabokbar A, Neale S, Itonaga I, Torisu T, Athanasou NA. The effect of macrophage colony stimulating factor and other humoral factors (IL$1,-3,-6$ and -11 , tumor necrosis factor $-\alpha$ and granulocyte-macrophage colony stimulating factor) on human osteoclast formation from circulating cells. Bone 2001;28:261-7.

5 Gravallese EM, Manning C, Tsay T, Naito A, Pan C, Amento E, et al. Synovial tissue in rheumatoid arthritis is a source of osteoclast differentiation factor. Arthritis Rheum 2000;43:250-8.

6 Shigeyama Y, Pap T, Kunzler P, Simmen BR, Gay RE, Gay S. Expression of osteoclast differentiation factor in rheumatoid arthritis. Arthritis Rheum 2000;43:2523-30

7 Crotti TN, Smith MD, Weedon H, Ahern MJ, Findlay DM, Kraan MC, et al. Receptor activator NF-kappa B ligand (RANKL) expression in synovial tissue from patients with rheumatoid arthritis, spondyloarthropathy, osteoarthritis, and from normal patients: semiquantitative and quantitative analysis. Ann Rheum Dis 2002;61:1047-54.

8 Yocum DE. T-cells: pathogenic cells and therapeutic targets in rheumatoid arthritis. Semin Arthritis Rheum 1999:29:27-35.

9 Tak PP, Bresnihan B. The pathogenesis and prevention of joint damage in rheumatoid arthritis. Arthritis Rheum 2000;43:2619-33.

10 Horton JE, Oppenheim JJ, Mergenhagen SE, Raisz LG. Macrophagelymphocyte synergy in the production of osteoclast activating factor. J Immunol 1974;113:1278-87.

11 Bertolini DR, Nedwin GE, Bringman TS, Smith DD, Mundy GR. Stimulation of bone resorption and inhibition of bone formation in vitro by human tumour necrosis factors. Nature 1986:319:516-18.

12 Dewhirst FE, Stashenko P, Mole JE, Tsurumachi T. Purification and partial sequence of human osteoclast-activating factor: identity with interleukin-1. $J$ Immunol 1985;135:2562-7.

13 Hofbaver LC, Lacey DL, Dunstan CR, Spelsberg TC, Riggs BL, Khosla S. Interleukin- 1 and tumor necrosis factor- $\alpha$, but not interleukin- 6 , stimulate osteoprotegerin ligand gene expression in human osteoblastic cells. Bone 1999;25:255-9.

14 Azuma Y, Kaji K, Katogi R, Takeshita S, Kudo A. Tumor necrosis factor- $\alpha$ induces differentiation of and bone resorption by osteoclasts. J Biol Chem 2000;275:4858-64.

15 Kobayashi K, Takahashi N, Jimi E, Udagawa N, Takami M, Kotake S, et al. Tumor necrosis factor alpha stimulates osteoclast differentiation by a mechanism independent of the ODF/RANKL-RANK interaction. J Exp Med 2000;191:275-85.

16 Fuller K, Murphy C, Kirstein B, Fox SW, Chambers TJ. TNF potently activates osteoclasts, through a direct action independent of and strongly synergistic with RANKL. Endocrinology 2002;143:1108-18.

17 Komine M, Kukita A, Kukita T, Ogata Y, Hotokebuchi T, Kohashi O. Tumor necrosis factor $\alpha$ co-operates with receptor activator of nuclear factor $\kappa B$ ligand in the generation of osteoclasts in stromal cell-depleted rat bone marrow cell culture. Bone 2001;28:474-83.

18 Lam J, Takeshita S, Barker JE, Kanagawa O, Ross FP, Teitelbaum SL. TNF $\alpha$ induces osteoclastogenesis by direct stimulation of macrophages exposed to permissive levels of RANK ligand. J Clin Invest 2000;106:1481-8.

19 Lader CS, Flanagan AM. Prostglandin $E_{2}$, interleukin $1 \alpha$ and tumor necrosis factor- $\alpha$ increase human osteoclast formation and bone resorption in vitro. Endocrinology 1998;139:3157-64.

20 Massey HM, Scopes J, Horton M, Flanagan AM. Transforming growth factorbeta 1 (TGF-beta) stimulates the osteoclast-forming potential of peripheral blood hematopoietic precursors in a lymphocyte-rich microenvironment. Bone $2001 ; 28: 577-82$

21 Nicholson GC, Malakellis M, Collier F, Cameron PU, Holloway WR, Gough TJ, et al. Induction of osteoclasts from CD14-positive human peripheral blood mononuclear cells by receptor activator of nuclear factor $\mathrm{\kappa B}$ ligand (RANKL). Clin Sci 2000;99:133-40

22 Chabaud $M$, Miossec P. The combination of tumor necrosis factor $\alpha$ blockade with interleukin-1 and interleukin-17 blockade is more effective for controlling synovial inflammation and bone resorption in an ex vivo model. Arthritis Rheum 2001;44:1293-303.

23 Dayer JM, Bresnihan B. Targeting interleukin-1 in the treatment of rheumatoid arthritis. Arthritis Rheum 2002;46:574-8.

24 Lipsky PE, van der Heijde DMFM, St Clair EW, Furst DE, Breedveld FC, Kalden JR, et al. Infliximab and methotrexate in the treatment of rheumatoid arthritis. Anti-Tumor Necrosis Factor Trial in Rheumatoid Arthritis with Concomitant Therapy Study Group. N Engl J Med 2000;343:1594-602.

25 Pettit AR, Ji H, von Stechow D, Müller R, Goldring SR, Choi Y, et al. TRANCE/ RANKL knockout mice are protected from bone erosion in a serum transfer model of arthritis. Am J Pathol 2001;159:1689-99.

26 Kong YY, Feige U, Sarosi I, Bolon B, Tafuri A, Moroney S, et al. Activated Tcells regulate bone loss and joint destruction in adjuvant arthritis through osteoprotegerin ligand. Nature 1999;402:304-8.

27 Ogata Y, Kukita A, Kukita T, Komine M, Miyahara A, Miyazaki S, et al. A novel role of IL-15 in the development of osteoclasts: inability to replace its activity with IL-2. J Immunol 1999;162:2754-60.

28 Chabaud M, Durand JM, Buchs N, Fossiez F, Page G, Frappant L, et al. Human interleukin-17: a T-cell-derived proinflammatory cytokine produced by the rheumatoid synovium. Arthritis Rheum 1999;42:963-70.

29 Kudo O, Fujikawa Y, Itonaga I, Sabokbar A, Torisu T, Athanasou NA Proinflammatory cytokine (TNF $\alpha / \mathrm{IL}-1 \alpha$ ) induction of human osteoclast formation. J Pathol 2002; 198:220-7. 
30 Sabokbar A, Kudo O, Athanasou NA. Two distinct cellular mechanisms of osteoclast formation and bone resorption in periprosthetic osteolysis. J Orthopaed Res 2003;21:73-80.

31 Hirayama T, Danks L, Sabokbar A, Athanasou NA. Osteoclast formation and activity in the pathogenesis of osteoporosis in rheumatoid arthritis. Rheumatology (Oxford) 2002;41:1232-9.

32 Erwig L-P, Kluth DC, Walsh GM, Rees AJ. Initial cytokine exposure determines function of macrophages and renders them unresponsive to other cytokines. $J$ Immunol 1998;161:1983-8.
33 Fox SW, Fuller K, Bayley KE, Lean JM, Chambers TJ. TGF-beta and IFN gamma direct macrophage activation by TNF-alpha to osteoclastic or cytocidal phenotype. J Immunol 2000;165:4957-63.

34 Gravallese EM, Galson DL, Goldring SR, Auron PE. The role of TNF-receptor family members and other TRAF-dependent receptors in bone resorption. Arthritis Res 2001;3:6-12.

35 Zhang YH, Heulsmann A, Tondravi MM, Mukherjee A, Abu-Amer Y. Tumor necrosis factor alpha stimulates RANKL induced osteoclastogenesis via coupling of TNF type 1 receptor and RANK signalling pathways. J Biol Chem 2001;276:563-8.

\section{Get published within days of acceptance with} ARD

We are delighted to announce that the Annals of the Rheumatic Diseases launched a "publish ahead of print" programme in February 2004. Selected papers are fast tracked and published online months before they appear in the print journal.

Papers of major significance to the international rheumatology community are published within days of acceptance. The first published article is the raw accepted manuscript; edited and typeset versions are also published as soon as they are available.

In addition to being available on ARD Online, the publish ahead of print articles are searchable through PubMed/ Medline-establishing primacy for your work. They are linked from the ARD Online home page.

$A R D$ 's publish ahead of print programme is unique among the major rheumatology journals - to take advantage of this service submit your papers to Annals of the Rheumatic Diseases using our online submission and review system Bench>Press (http://submit-ard. bmijournals.com). For further information contact ARD@bmigroup.com. 